\title{
The Clinical Significance of Complete Blood Count Parameters for Frequent Emergency Department Admissions and Re-hospitalisation in Patients with Asthma Attacks Requiring Hospitalisation
}

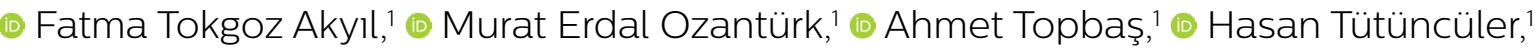 \\ (1) Gökhan Söğüt, ${ }^{1}$ (1) Mustafa Akyıl, ${ }^{2}$ 니 Tulin Sevim³
}

'Department of Chest Diseases, Canakkale Mehmet Akif Ersoy State Hospital, Çanakkale, Turkey 2Department of Thoracic Surgery, Canakkale Mehmet Akif Ersoy State Hospital, Çanakkale, Turkey

${ }^{3}$ Department of Chest Diseases, Sureyyapasa Chest Diseases and

Thoracic Surgery Training and Research Hospital, İstanbul, Turkey

Submitted: 31.12 .2018 Accepted: 24.05.2019

Correspondence: Fatma Tokgoz Akyıl

Çanakkale Mehmet Akif Ersoy Devlet Hastanesi, Göğüs Hastalıkları Kliniği, Çanakkale, Turkey E-mail: fatmatokgoz86@gmail.com

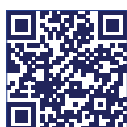

Keywords: Asthma; eosinophil; lymphocyte; neutrophil.

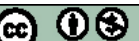

This work is licensed under a This work icensed und 0 Crernational License.

\begin{abstract}
Objective: The aim of this study was to investigate factors associated with emergency department (ED) admission and re-hospitalization within I year following a baseline asthma attack requiring hospitalization, and to investigate the role of complete blood count (CBC) parameters in these attacks.
\end{abstract}

Methods: This was a retrospective, observational study of patients hospitalized due to an asthma attack between September 2015 and September 2017. The number of ED admissions and re-hospitalizations due to an asthma attack within a year of the original admission was investigated and predictive factors related to frequent ED admissions $(\geq 2)$ and re-hospitalization were analyzed.

Results: Among the 59 study patients, the mean age was $58 \pm 16$ years and 9 (I5\%) were male. Follow-up data revealed that $15(25 \%)$ patients had frequent ED admissions and 20 (34\%) patients were re-hospitalized within a year. Demographic details, additional diseases, and the baseline C-reactive protein level were not found to be predictive of subsequent asthma attacks. A baseline higher count of leukocytes $(p=0.003)$ and neutrophils $(p=0.00 \mathrm{I})$ and the ratio of neutrophils to lymphocytes (NLR) $(p=0.017)$ were found to be statistically significant in patients with frequent ED admissions. The risk of re-hospitalization was found to increase with a higher baseline NLR $(p=0.022)$ and platelet-to-lymphocyte ratio $(P L R)$ $(p=0.024)$.

Conclusion: $\mathrm{CBC}$ analysis can provide important clues for prognosis in asthma attacks. The NLR should be considered as a possible indicator of frequent ED admissions, and the NLR and PLR should be taken into account as potential signs of re-hospitalization.

\section{INTRODUCTION}

Asthma attacks are conditions which require urgent intervention, cause significant morbidity and might be lifethreatening. The attacks are the most common cause of emergency department admissions and constitute an important part of the expenditures related to asthma. ${ }^{[1]}$ Despite the current medical treatments, there has been no significant decrease in emergency admissions. ${ }^{[2,3]}$

The number of emergency department admissions and hospitalizations are important determinants for the severity of asthma and attack which might be mortal. Some asthma patients have frequent attacks and it could not have been verified clearly which factors are associated with frequent attacks. It has been reported that the factors such as age ${ }^{[4,5,6]}$, non-white race ${ }^{[4,6]}$, low socioeconomic leve ${ }^{[7]}$, female gender ${ }^{[5,6]}$, psychopathological status, chronic sinusitis, gastroesophageal reflux disease, obstructive sleep apnea syndrome ${ }^{[8]}$ are associated with frequent attacks. Nevertheless, there are also studies that have not determined the relationship between the age ${ }^{[7,9]}$ and gen$\operatorname{der}^{[4,7,9]}$ and the attacks. 
In recent years, the effect of whole blood count parameters on the severity and progression of chronic diseases has been questioned. The ratio of neutrophils to lymphocytes (NLR) as an indicator of inflammation has been found to be associated with the severity of the disease and hospitalizations in chronic obstructive pulmonary disease, ${ }^{[10]}$ diabetes mellitus and hypertension. ${ }^{[10,11]}$ For the association of asthma with whole blood count parameters, there are few studies conducted with different patient groups and different methods. In uncontrolled asthma patients, the ratio of eosinophils to lymphocytes (ELR), eosinophils to neutrophils (ENR) and NLR values were found to be high in eosinophilic phenotype. ${ }^{[12]}$ In children with asthma, NLR has been associated with hospitalization and attacks. $[13,14]$ The results of the study investigating the relationship between the number of episodes and NLR values in adult asthma show some differences. ${ }^{[9,15]}$

The aim of this study was to investigate the factors associated with asthma attacks requiring emergency admissions and re-hospitalization in a year following asthma attacks requiring hospitalization and to investigate the relationship between NLR and other blood count parameters and the attacks.

\section{MATERIALS AND METHODS}

This is a single-center, retrospective observational study conducted in a pulmonology clinic of a secondary state hospital.

From the hospital automation system between September 2015 and September 2017, the medical files of 131 patients which were hospitalized with the diagnosis of asthma [ICD-10 $\left(10^{\text {th }}\right.$ revision of the international classification of diseases): J45, J45.0, J45.I, J45.8, J45.9 codes] were evaluated.

\section{Inclusion criteria:}

- The patients whose asthma diagnosis has been confirmed by a pulmonologist ${ }^{[16]}$

- The patients who have asthma as a hospitalization reason

- The patients with one-year follow-up in our hospital

\section{Exclusion criteria:}

- Hospitalizations not caused by asthma attacks (diagnoses such as pneumonia, malignancy, interstitial lung failure, decompensated heart failure, restrictive lung failure, pulmonary embolism)

- Patients who do not continue clinical follow-up in our hospital

Patients with recurrent hospitalizations were enrolled once with their first hospitalization. 59 patients hospitalized with asthma attack and followed up in our clinic were included in the study (Fig. I). One-year follow-up of the patients after the attack was investigated.

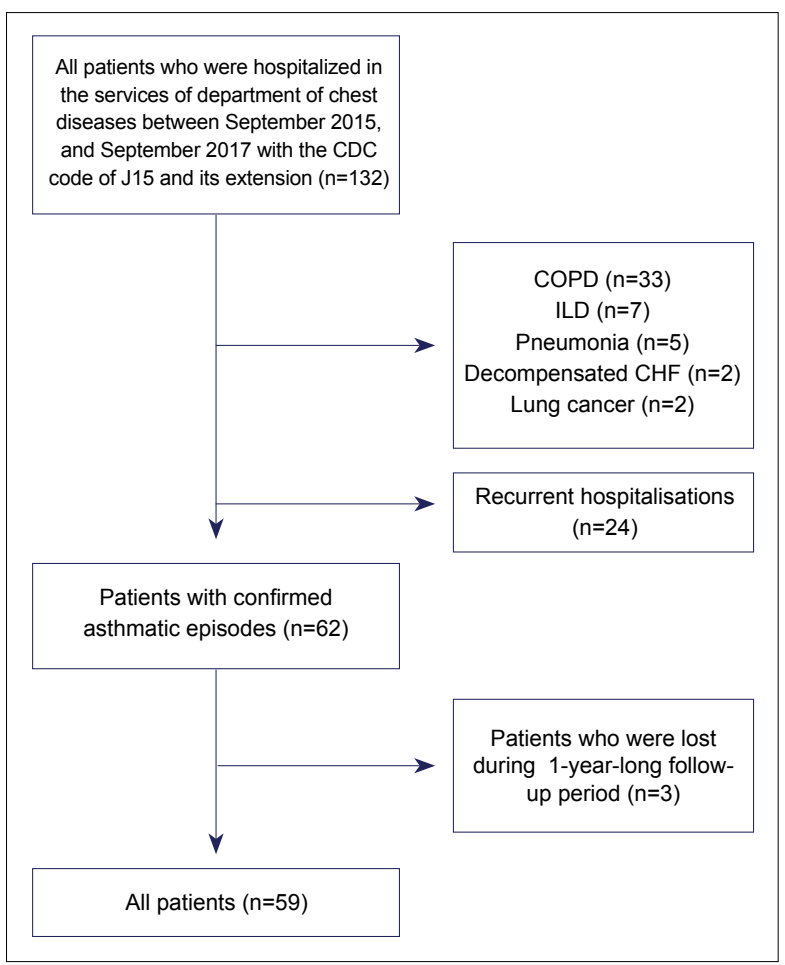

Figure 1. Patient selection flow chart.

\section{Recorded data}

Demographic characteristics, comorbidities, basal whole blood count parameters including leukocyte $\left(10^{3} / \mathrm{L}\right)$, neutrophil $\left(10^{3} / \mathrm{L}\right)$, lymphocyte $\left(10^{3} / \mathrm{L}\right)$, platelet $\left(10^{3} / \mathrm{L}\right)$, eosinophil $\left(10^{3} / \mathrm{L}\right)$, eosinophil $(\%)$, hemoglobin $(\mathrm{g} / \mathrm{dl})$ and Creactive protein (CRP) $(\mathrm{mg} / \mathrm{l})$ values, PA chest radiographs and other investigations were performed. All hospital admissions from the automation system were examined and additional diseases were re-investigated. Hospitalization periods were recorded. Pulmonology outpatient clinic and asthma-related emergency department admissions of all patients were reviewed within 12 months from the date of discharge and re-hospitalization requirements were investigated. Treatment results and hospitalization requirements were recorded from all emergency admissions. The ratio of neutrophils to lymphocytes (NLR), the ratio of platelets to lymphocytes (PLR), the ratio of eosinophils to lymphocytes (ELR), the ratio of eosinophils to neutrophils (ENR) were calculated.

\section{Study design}

All patients were divided into 2 groups, according to the number of emergency admissions as less than 2 emergency department admissions and $\geq 2$ emergency admissions. And the factors associated with frequent emergency visits were investigated.

\section{Statistical analysis}

The data were expressed as mean \pm standard deviation. The parameters associated with frequent emergency de- 
partment admissions were calculated by student's t-test and chi-square methods. The factors associated with rehospitalization within a year were investigated by Cox regression analysis. The data were recorded in SPSS (SPSS for Windows, version 16.0; SPSS Inc.; Chicago, IL, USA) 16.0 statistics program. The values were calculated in $95 \%$ confidence interval and $p$ value $<0.05$ was considered as significant.

\section{RESULTS}

The mean age of the patients included in the study was $58 \pm 16$ years and 9 (15\%) of them were male. Forty-six (78\%) patients had at least one comorbidity. The most commonly recorded diseases were hypertension (39\%), anxiety disorder or depression (27\%) and diabetes mellitus (24\%). The mean hospital stay was $6 \pm 3.4$ (I-19) days.

In the follow-up of the patients, the mean number of outpatient admissions was 2.8 $\pm 2.1(0-8), I .1 \pm 1.7(0-8)$, and hospitalization $0.5 \pm \mathrm{I}(0-4)$ within one year. While twenty-nine $(49 \%)$ patients never applied to the emergency department, 15 (25\%) patients admitted once. Other patients were admitted to the emergency department 2-8 times. When the factors associated with frequent $(\geq 2)$ emergency admissions were investigated; there was no statistically significant relationship between demographic features and comorbidities $(p>0.05)$. Basal leukocyte $(p=0.003)$ and basal neutrophil $(p=0.001)$ values were higher in patients with frequent emergency visits. There was no significant relationship between CRP, hemoglobin and eosinophil values ( $p>0.05)$. PLR, ELR and ENR values of hematological parameters were not correlated with the frequency of attacks; higher NLR $(p=0.017)$ values were found in patients with frequent emergency visits (Table I).

Following the first hospitalization, re-hospitalization was recorded in 20 (34\%) patients. The hospitalizations occurred after a median of $9 \pm 1.4$ months. There was no correlation between demographic characteristics and comorbidities and re-hospitalization $(p>0.05)$. Leukocyte, eosinophil, thrombocyte hemoglobin values of whole blood count parameters were not associated with re-hospitalizations $(p>0.05)$. High NLR $(p=0.022)$ and high PLR $(p=0.024)$ values increased the risk of attacks requiring rehospitalization (Table 2).

\section{DISCUSSION}

When the morbidity, labor loss and high health expenditures caused by asthma attacks are considered, it is important to identify the risk group. In our study, the relation-

Table I. Factors associated with frequent emergency admission after asthma attack

\begin{tabular}{|c|c|c|c|c|}
\hline & $\begin{array}{c}\text { Total } \\
n=59 \\
(n=44)\end{array}$ & $\begin{array}{c}<2 \text { emergency } \\
\text { admissions } \\
(n=15)\end{array}$ & $\begin{array}{c}\geq 2 \text { emergency } \\
\text { admissions }\end{array}$ & $\mathbf{p}$ \\
\hline \multicolumn{5}{|l|}{ Gender } \\
\hline Male & $9(15)$ & $7(16)$ & $2(13)$ & 0.999 \\
\hline Female & $50(85)$ & $37(84)$ & $13(87)$ & \\
\hline Age & $58 \pm 16(20-88)$ & $58 \pm 16$ & $58 \pm 14$ & 0.903 \\
\hline Any comorbidities & $46(78)$ & $33(75)$ & $13(87)$ & 0.482 \\
\hline Hypertension & $23(39)$ & $17(39)$ & $6(40)$ & 1.000 \\
\hline Anxiety/depression & $16(27)$ & $12(27)$ & $3(20)$ & 0.738 \\
\hline Diabetes Mellitus & $14(24)$ & $10(23)$ & $4(27)$ & 0.736 \\
\hline Cardiac disease & $8(14)$ & $6(14)$ & $2(13)$ & 1.000 \\
\hline Thyroid disease & $5(9)$ & $3(7)$ & $2(13)$ & 0.593 \\
\hline Allergic rhinitis & $7(12)$ & $6(14)$ & I (7) & 0.666 \\
\hline Gastroesophageal reflux & $5(9)$ & $4(9)$ & I (7) & 1.000 \\
\hline Leukocyte $\left(10^{3} / \mathrm{L}\right)$ & $9.7 \pm 4.1$ & $8.8 \pm 3.3$ & $12.4 \pm 5.1$ & 0.003 \\
\hline Eosinophil (\%) & $2.1 \pm 3.3(0-16)$ & $2.0 \pm 3.3$ & $2.4 \pm 3.3$ & 0.750 \\
\hline Neutrophil $\left(10^{3} / \mathrm{L}\right)$ & $6.9 \pm 3.6(1.4-20.3)$ & $6.0 \pm 2.7$ & $9.4 \pm 4.7$ & 0.001 \\
\hline Lymphocyte (103/L) & $2.4 \pm 3.1(0.4-22.5)$ & $2.6 \pm 3.6$ & $1.9 \pm 1.2$ & 0.502 \\
\hline Thrombocyte ( $\left(0^{3} / \mathrm{L}\right)$ & $266 \pm 78(99-465)$ & $253 \pm 66$ & $304 \pm 98$ & 0.058 \\
\hline CRP (mg/L) & $41.7 \pm 58.7$ & $36.8 \pm 47$ & $55 \pm 83$ & 0.307 \\
\hline Hemoglobin (g/dL) & $12.7 \pm 1.6$ & $12.6 \pm 1.7$ & $12.9 \pm 1.5$ & 0.598 \\
\hline NLR & $5.1 \pm 4.8$ & $4.2 \pm 3.5$ & $7.6 \pm 7.1$ & 0.017 \\
\hline PLR & $189 \pm 146$ & $175 \pm 130$ & $229 \pm 185$ & 0.225 \\
\hline ELR & $0.09 \pm 0.15$ & $0.09 \pm 0.17$ & $0.08 \pm 0.09$ & 0.796 \\
\hline ENR & $0.03 \pm 0.06$ & $0.03 \pm 0.05$ & $0.05 \pm 0.07$ & 0.537 \\
\hline Length of stay in hospital (day) & $6.0 \pm 3.4$ & $5.9 \pm 3.6$ & $6.4 \pm 3.0$ & 0.666 \\
\hline
\end{tabular}


Table 2. Factors associated with the risk of exacerbation requiring hospitalization within one year after an asthma attack

\begin{tabular}{|c|c|c|c|}
\hline & HR & Cl $(95 \%)$ & $\mathbf{p}$ \\
\hline Gender & 0.990 & $0.963-1.018$ & 0.477 \\
\hline Age & 0.630 & $0.210-1.889$ & 0.432 \\
\hline Length of stay in hospital (day) & 1.019 & $0.906-1.146$ & 0.758 \\
\hline Hypertension & 0.903 & $0.369-2.210$ & 0.824 \\
\hline Anxiety/depression & 0.983 & $0.357-2.705$ & 0.974 \\
\hline Diabetes mellitus & 1.253 & $0.419-3.749$ & 0.680 \\
\hline Cardiac disease & 0.427 & $0.155-1.177$ & 0.128 \\
\hline Thyroid disease & 0.861 & $0.200-3.710$ & 0.843 \\
\hline Allergic rhinitis & 3.018 & $0.404-5.579$ & 0.201 \\
\hline Gastroesophageal reflux & 1.817 & $0.243-13.665$ & 0.523 \\
\hline Leukocyte $\left(10^{3} / \mathrm{L}\right)$ & 1.083 & $0.970-1.209$ & 0.172 \\
\hline Eosinophil (\%) & 1.056 & $0.939-1.188$ & 0.397 \\
\hline Neutrophil $\left(10^{3} / \mathrm{L}\right)$ & 1.099 & $0.950-1.233$ & 0.242 \\
\hline Lymphocyte (103/L) & 0.661 & $0.399-1.094$ & 0.038 \\
\hline Thrombocyte (103/L) & 1.004 & $0.997-1.008$ & 0.192 \\
\hline CRP (mg/L) & 1.004 & $0.997-1.012$ & 0.313 \\
\hline Hemoglobin (g/dL) & 0.999 & $0.760-1.313$ & 0.993 \\
\hline NLR & 1.090 & $1.020-1.165$ & 0.022 \\
\hline PLR & 1.003 & $1.001-1.005$ & 0.024 \\
\hline ELR & 2.833 & $0.284-28.306$ & 0.418 \\
\hline ENR & 20.804 & $0.489-84.161$ & 0.125 \\
\hline
\end{tabular}

CRP: C-reactive protein; ELR: Erythrocytes to lymphocytes ratio; ENR: Erythrocytes to neutrophils ratio; NLR: Neutrophils to lymphocytes ratio; PLR: Platelets to lymphocytes ratio.

ship between adult asthma attacks and the risk of relapses was examined and important results were obtained regarding complete blood count parameters. High NLR values in episodes requiring hospitalization were determined to be a risk indicator for frequent emergency admissions and re-hospitalization in the following year. Furthermore, the relationship between high PLR values and re-hospitalization was demonstrated for the first time.

The rates of hospital admissions, exacerbations and hospitalizations in asthma patients vary widely in relation to the clinical setting, study group and study method. Griswold et al. evaluated 3000 emergency admissions due to asthma attacks in the United States. In the previous year, $73 \%$ of these patients reported at least one more and $21 \%$ had more than five emergency admissions. ${ }^{[4]}$ The number of hospitalizations with asthma exacerbation was $2.1 \pm 2.3$ and the number of emergency admissions was $4.2 \pm 4.1$ in one year. ${ }^{[17]}$ In another study, it was analyzed that $\% 70$ of uncontrolled asthma patients required outpatient visits and $36 \%$ of them required emergency visits in one year and $14 \%$ of these patients required hospitalization. In asthma patients under control, these rates were found to be $43 \%, 10 \%$ and $3 \%$, respectively. ${ }^{[18]}$ Adams et al. reported that in the first year following hospitalization due to attacks, $\geq 2$ emergency admissions were found in $11 \%$ and re-hospitalizations in $13 \%{ }^{[19]}$ In our study, less than half of the patients admitted to the emergency room after the attack and more than one third of the patients were hospitalized again.

Emre et al. reported that the average hospitalization day due to asthma attack was $8.5 \pm 4.6$ days in the Pulmonology Clinics of a state hospital in Manisa. ${ }^{[20]}$ In our study, the mean length of stay was two days shorter. It has been reported that meteorological changes might be associated with the attacks. ${ }^{[2]}$ We believe that different hospitalization times may be associated with meteorological changes and further studies are needed on the factors affecting the attack severity and duration.

Different results have been presented regarding the factors affecting the frequency of attacks. Age $\mathrm{e}^{[4,5,6,8]}$ and female gender ${ }^{[5]}$ have been reported as risk factors for frequent attacks. In addition to studies reporting that the sex and frequency of attacks were unrelated ${ }^{[4,6]}$; Eisner et $\mathrm{a}^{[7,9]}$ reported that there was no relationship between demographic features and frequency of attacks and similarly in their study, no relationship was found between age and gender and frequency of attacks. In asthma exacerbations, the relationship between psychopathological status and chronic sinusitis has been demonstrated for the frequency of exacerbations which was recorded in the previous year ${ }^{[8]}$ In our study, no association of comorbidities with attacks was found. We think that the association of comorbidities and demographic characteristics with the frequency of attacks should be investigated in studies with larger sample size.

In recent years, the use of whole blood count parameters as an indicator of inflammation in asthma has been questioned. Studies with different methods and different patient groups have been published. High NLR values have been reported to increase the risk of asthma attacks for all age groups. ${ }^{[9,14]}$ Gungen et al. have compared stable asthma patients with healthy control group. In asthma, NLR values were found to be higher and it increased when the disease was not under control, and the number of attacks and NLR values were found to be unrelated. ${ }^{[15]}$ In the pediatric patient group, higher NLR values than in healthy volunteers have been reported, while hospitalization and NLR have been reported unrelated. ${ }^{[13]}$ Zhang et al. have found that peripheral blood ELR, ENR and NLR values were correlated among asthma phenotypes in asthmatic patients receiving treatment but not under control. ${ }^{[12]}$ In our study, ELR and ENR values were not correlated with the number of attacks and hospitalizations. However, NLR values were higher in patients with frequent emergency admissions and those who needed re-hospitalization.

The neutrophils are thought to play a key role in triggering and resolving an asthma attack. ${ }^{[22]}$ Neutrophils have been shown to cause airway constriction in severe asthma rather than stable asthma. ${ }^{[23,24]}$ The lymphocytes are reduced in acute stress conditions such as myocardial infarction. ${ }^{25]}$ NLR was thought to be more accurate than neutrophil or lymphocyte analysis alone. ${ }^{[2]}$ Our results suggest that high 
NLR is associated with both frequent emergency admissions and re-hospitalization. The neutrophils alone were also associated with frequent emergency admissions.

The platelets have been shown to play important roles in immune system regulation and inflammation. Triggering factors stimulate the release of inflammatory cytokines and stimulate white blood cells. ${ }^{[27,28]}$ It has been shown that platelets are activated in asthma and CDI54 expression is increased. ${ }^{[29,30]}$ CDI54 release has been shown to activate platelets during allergen sensitization in asthma, stimulating other white blood cells to cause inflammation to become more pronounced. ${ }^{[3]}$ In the literature, we could not find a study investigating the relationship between asthma attacks and platelet count and PLR. In our study, the platelets were not associated with frequent emergency admissions, whereas high PLR values were associated with severe episodes requiring hospitalization.

The most important limitation of this study was that it was retrospective and uni-centered and the physiological parameters of the patients were not recorded. As a retrospective study, educational status, treatment protocols and treatment compliance of the patients could not be examined. However, all patients were followed up by the pulmonologists at our center. The fact that all district hospitals are connected to the same automation system has ensured that comorbidities and hospital admissions were reliably detected.

\section{CONCLUSION}

In conclusion, rapid, simple and easily accessible complete blood count analysis in asthma attacks can provide important clues for the prognosis of the patients. For frequent emergency admissions, NLR values and for the attacks which require re-hospitalization, NLR and PLR values should be considered as an indicator of inflammation.

Ethics Committee Approval

Ethics committee approval with the number 20 I I-KAEK27/2018-1800156929 was received for the study.

Informed Consent

Informed consent was not obtained due to the retrospective nature of the study.

Peer-review

Internally peer-reviewed.

Authorship Contributions

Concept: F.T.A., M.E.O., A.T., H.T., G.S., M.A., T.S.; Design: F.T.A., M.E.O., A.T., H.T., G.S., M.A., T.S.; Supervision: F.T.A., M.E.O., A.T., H.T., G.S., M.A., T.S.; Fundings: F.T.A., M.E.O., A.T.; Materials: F.T.A., M.E.O., A.T., H.T., G.S.; Data: F.T.A., M.E.O., A.T., H.T., G.S.; Analysis: F.T.A., M.A.; Literature search: F.T.A., T.S.; Writing: F.T.A., M.A., T.S.; Critical revision: F.T.A., T.S.

Conflict of Interest

None declared.

\section{REFERENCES}

1. Gemicioğlu B. Atak kavramı ve tedavi yaklaşımı. In: Gemicioğlu B, editör. Tanımdan tedaviye astım. İstanbul: Turgut yayıncılık; 2004. p. 457-65.

2. Jackson DJ, Sykes A, Mallia P, Johnston SL. Asthma exacerbations: origin, effect, and prevention.J Allergy Clin Immunol 2001;128:1165-74.

3. Fuhlbrigge AL, Adams RJ, Guilbert TW, Grant E, Lozano P, Janson SL, et al. The burden of asthma in the United States: level and distribution are dependent on interpretation of the national asthma education and prevention program guidelines. . Am J Respir Crit Care Med 2002;166:1044-9. [CrossRef]

4. Griswold SK, Nordstrom CR, Clark S, Gaeta TJ, Price ML, Camargo CA Jr. Asthma exacerbations in North American adults: who are the "frequent fliers" in the emergency department? Chest 2005;127:1579-86.

5. Tattersfield AE, Postma DS, Barnes PJ, Svensson K, Bauer CA, O'Byrne PM, et al. Exacerbations of asthma: a descriptive study of 425 severe exacerbations. The FACET international study group. Am J Respir Crit Care Med 1999;160:594-9. [CrossRef]

6. Miller MK, Lee JH, Miller DP, Wenzel SE. Recent asthma exacerbations: a key predictor of future exacerbations. Respir Med 2007;101:481-9. [CrossRef]

7. Eisner MD, Katz PP, Yelin EH, Shiboski SC, Blanc PD. Risk factors for hospitalization among adults with asthma: the influence of sociodemographic factors and asthma severity. Respir Res 2001;2:53-60.

8. ten Brinke, Sterk PJ, Masclee AA, Spinhoven P, Schmidt JT, Zwinderman $\mathrm{AH}$, et al. Risk factors of frequent exacerbations in difficultto-treat asthma. Eur Respir J 2005;26:812-18. [CrossRef]

9. Mochimaru T, Ueda S, Suzuki Y, Asano K, Fukunaga K. Neutrophilto-lymphocyte ratio as a novel independent predictor of severe exacerbation in patients with asthma. Ann Allergy Asthma Immunol 2019;122:337-9. [CrossRef]

10. Günay E, Sarınç Ulaşlı S, Akar O, Ahsen A, Günay S, Koyuncu T, et al. Neutrophil-to-lymphocyte ratio in chronic obstructive pulmonary disease: a retrospective study. Inflammation 2014;37:374-80. [CrossRef]

11. Imtiaz F, Shafique K, Mirza SS, Ayoob Z, Vart P, Rao S. Neutrophil lymphocyte ratio as a measure of systemic inflammation in prevalent chronic diseases in Asian population. Int Arch Med 2012;5:2. [CrossRef]

12. Zhang XY, Simpson JL, Powell H, Yang IA, Upham JW, Reynolds $\mathrm{PN}$, et al. Full blood count parameters for the detection of asthma inflammatory phenotypes. Clin Exp Allergy 2014;44:1137-45.

13. Dogru M, Yesiltepe Mutlu RG. The evaluation of neutrophil-lymphocyte ratio in children with asthma. Allergol Immunopathol (Madr) 2016;44:292-6. [CrossRef]

14. Nacaroglu HT, İsguder R, Bent S, Bahceci SE, Ceylan G, Korkmaz HA, et al. Can neutrophil/lymphocyte ratio be a novel biomarker of inflammation in children with asthma? Eur J Inflamm 2016;14:109-12.

15. Güngen AC, Aydemir Y. The correlation between asthma disease and neutrophil to lymphocyte ratio. Res J Allergy Immunol 2017;1:1-4.

16. Reddel HK, Bateman ED, Becker A, Boulet LP, Cruz AA, Drazen JM, et al. A summary of the new GINA strategy: a roadmap to asthma control. Eur Respir J 2015;46:622-39. [CrossRef]

17. Doğru S. Astım atağıyla takip edilen hastaların yaş gruplarına göre klinik özellikleri. Selçuk Üniversitesi Meram Tıp Fakültesi, Uzmanlık Tezi. 2009.

18. Peters SP, Jones CA, Haselkorn T, Mink DR, Valacer DJ, Weiss ST. Real-world Evaluation of Asthma Control and Treatment (REACT): findings from a national Web-based survey. J Allergy Clin Immunol 2007;119:1454-61. [CrossRef]

19. Adams RJ, Smith BJ, Ruffin RE. Factors associated with hospital admissions and repeat emergency department visits for adults with asthma. Thorax 2000;55:566-73. [CrossRef] 
20. Celdir Emre J, Özdemir Ö, Baysak A, Aksoy Ü, Özdemir P, Öz AT, et al. Cost of asthma hospitalizations in a pulmonary clinic of a state hospital Asthma Allergy Immunol 2014;12:140-5.

21. Beggs PJ. Adaptation to impacts of climate change on aeroallergens and allergic respiratory diseases. Int J Environ Res Public Health 2010;7:3006-21. [CrossRef]

22. Fahy JV. Eosinophilic and neutrophilic inflammation in asthma: insights from clinical studies. Proc Am Thorac Soc 2009;6:256-9.

23. Wenzel SE, Szefler SJ, Leung DY, Sloan SI, Rex MD, Martin RJ. Bronchoscopic evaluation of severe asthma. Persistent inflammation associated with high dose glucocorticoids. Am J Respir Crit Care Med. 1997;156:737-43. [CrossRef]

24. Fahy JV, Kim KW, Liu J, Boushey HA. Prominent neutrophilic inflammation in sputum from subjects with asthma exacerbation. J Allergy Clin Immunol 1995;95:843-52. [CrossRef]

25. Hoffman M, Blum A, Baruch R, Kaplan E, Benjamin M. Leukocytes and coronary heart disease. Atherosclerosis 2004;172:1-6. [CrossRef]
26. Wang Q, Ma J, Jiang Z, Ming L. Prognostic value of neutrophilto-lymphocyte ratio and platelet-to-lymphocyte ratio in acute pulmonary embolism: a systematic review and meta-analysis. Int Angiol 2018;37:4-11.

27. Semple JW, Italiano JE Jr, Freedman J. Platelets and the immune continuum. Nat Rev Immunol 2011;11:264-74. [CrossRef]

28. Yeaman MR. Platelets: at the nexus of antimicrobial defence. Nat Rev Microbiol 2014;12:426-37. [CrossRef]

29. Benton AS, Kumar N, Lerner J, Wiles AA, Foerster M, Teach SJ, et al. Airway platelet activation is associated with airway eosinophilic inflammation in asthma. J Investig Med 2010;58:987-90. [CrossRef]

30. Kowal K, Pampuch A, Kowal-Bielecka O, Iacoviello L, BodzentaLukaszyk A. Soluble CD40 ligand in asthma patients during allergen challenge. J Thromb Haemost 2006;4:2718-20. [CrossRef]

31. Tian J, Zhu T, Liu J, Guo Z, Cao X. Platelets promote allergic asthma through the expression of CD154. Cell Mol Immunol 2015;12:700-7. [CrossRef]

\section{Hastane Yatışı Gereken Erişkin Astım Ataklarında Tam Kan Sayımı Parametrelerinin Sık Acil Başvuruları ve Yeniden Hastane Yatışı liçin Prognostik Önemi}

Amaç: Bu çalışmanın amacı, hastane yatışı gerektiren astım ataklarını takiben, bir yıl içinde yeniden acil başvuruları ve hastane yatışı ile ilişkili faktörleri araştırmak, tam kan sayımı parametrelerinin ataklar ile ilişkisini incelemektir.

Gereç ve Yöntem: Çalışma, retrospektif gözlemsel bir çalışma olup Eylül 20।5-Eylül 2017 arasında kliniğimizde astım atağı nedeniyle yatırılan hastalar değerlendirildi. Hastaların demografik özellikleri, ek hastalıkları ve bazal kan sayımı parametreleri kaydedildi. Takip eden bir yıl içinde sık acil başvuruları $(\geq 2)$ ve yeniden hastane yatışı ile ilişkili faktörler analiz edildi.

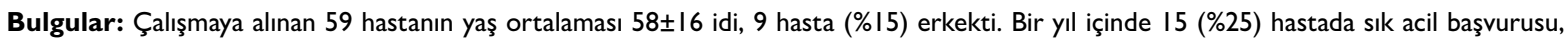
20 (\%34) hastada yeniden hastane yatışı kaydedildi. Demografik özellikler, ek hastalıklar ve bazal C-reaktif protein değerleri ile daha sonraki ataklar arasında ilişki saptanmadı $(p>0.05)$. Sık acil başvurusu olan hastalarda bazal lökosit $(p=0.003)$, nötrofil $(p=0.00 I)$ ve nötrofillerin lenfositlere oranı $(N L O)(p=0.017)$ istatistiksel olarak anlamlı yüksekti. Yeniden hastane yatışının ise yüksek bazal NLO ( $p=0.022)$ ve PLO $(p=0.024)$ değerleri ile ilişkili olduğu belirlendi.

Sonuç: Tam kan sayımı analizi astım ataklarında prognoz için önemli ipuçları sağlayabilir. Sık acil başvuruları riski için NLO; yeniden yatış gerekecek ataklar için ise NLO ve PLO değerleri dikkate alınmalıdır.

Anahtar Sözcükler: Astım; eozinofil; lenfosit; nötrofil. 